University for Business and Technology in Kosovo

UBT Knowledge Center

Oct 28th, 9:00 AM - Oct 30th, 5:00 PM

\title{
Improving non-native English students' communicative competence and collaboration skills through Virtual Simulations
}

\author{
Alisa Sadiku \\ University for Business and Technology, alisa.sadiku@ubt-uni.net
}

Follow this and additional works at: https://knowledgecenter.ubt-uni.net/conference

Part of the Communication Commons, and the Computer Sciences Commons

\section{Recommended Citation}

Sadiku, Alisa, "Improving non-native English students' communicative competence and collaboration skills through Virtual Simulations" (2016). UBT International Conference. 57.

https://knowledgecenter.ubt-uni.net/conference/2016/all-events/57

This Event is brought to you for free and open access by the Publication and Journals at UBT Knowledge Center. It has been accepted for inclusion in UBT International Conference by an authorized administrator of UBT Knowledge Center. For more information, please contact knowledge.center@ubt-uni.net. 
Book of Proceedings

International Conference on Computer Science and Communication Engineering

\title{
Improving non-native English students' communicative competence and collaboration skills through Virtual Simulations
}

\author{
Alisa Sadiku \\ UBT - Higher Education Institution, Lagjja Kalabria, 10000 p.n., \\ Prishtine, Kosovo \\ alisa.sadiku@ubt-uni.net
}

\begin{abstract}
Knowing how to communicate in the target language is the main goal of most language learners. Furthermore, it is very challenging for teachers to bring real world communication experiences in classroom settings where English is not the native language. Hence, in this paper I explore the role of virtual simulations in promoting communicational and collaboration opportunities to non-native speakers of English. In my research, I describe how virtual worlds improve communicative and collaborative skills of non-native speakers of English. Moreover, I investigate how virtual worlds can create a learner centered environment where students take control of their own language production. And third, I explore how the affordances of virtual worlds can enhance non-native English students' communication and collaboration by engaging them in contextual and authentic environment.
\end{abstract}

Keywords: Computer Assisted Language Learning, Virtual worlds, Communication, Collaboration.

\section{Introduction}

As English is becoming a dominant world language, the need for good communication skills has increased too. Thus, the educational system is imposing a demand for more teaching strategies that improve the quality of teaching communicative and collaborative language skills. Also, the advent of technology has led to major changes in the world. This rapid acceleration of technology has shown a great impact in the field of education. Moreover, as a significant educational component, computers and the internet are shown quite successful at creating environments that offer students opportunities to practice communication. Hence, this paper is focused on how technology, in particular virtual worlds (VWs), can provide communication and collaboration in the target language.

\subsection{Going beyond traditional language teaching}

Placing language within context and promoting an authentic environment plays a significant role in language acquisition, particularly when it comes to teaching the social aspects of a language. Consequently, as natural language cannot exist in a vacuum (Gee, 2001, p.715), teachers find it very challenging to integrate and promote this kind of realistic situation that will develop students' communicative competence and collaboration skills. In addition, students themselves 
Improving non-native English students' communicative competence and collaboration skills through Virtual Simulations

want to go beyond the traditional conceptual and abstract teacher-centered learning and apply the target language in "real life" situations.

These new learners, "the digital natives" (Prensky, 2001, p.1), do not fit the traditional teaching/learning model since most of them are surrounded with different means, particularly technological advancements that help them face the obstacles of language learning. There are several features that these learners expect from today's language learning instructions. Above all, they expect to multitask and to be networked, to receive information fast and to be exposed to more graphics and games rather than "serious" work (ibid, p.2). Therefore, one of the biggest challenges for today's teachers is to find methods and strategies that will help them incorporate these new technological requirements in their teaching.

VWs have a great impact on overcoming the lack of opportunities to communicate and collaborate in authentic situations. They distinguish from games, since the aim of VWs is not to win or lose but rather to perform real life functions like shopping, working, traveling, meeting friends etc.

\section{Research field}

A great deal of second language acquisition theories and approaches are being supported by virtual realities, one of which is the student-centered learning approach, where students are given the opportunity to participate in their own language knowledge construction instead of applying rote repetition and memorization only (Jung, 2002). Another benefit is that the anonymity behind the avatars ensures a stress diminished, non-threatening environment where students experience less apprehension and are eager to take more risks than in face-to-face interactions. This supports what Krashen (1985) refers to as the affective filter hypothesis which suggests that affective factors like anxiety may cause "a mental block that prevents input from reaching the language acquisition device" (p.100). Furthermore, virtual realities endeavor to make students participate actively without having concerns about their mistakes, but instead prioritize communication over accuracy, a concept that Krashen (1985) calls natural communicative input. According to this "acquisition requires meaningful interaction in the target language, when speakers are concerned not with the form of their utterances but with the messages they are conveying and understanding" (p. 1).

Another crucial benefit of virtual simulations is promoting the model, called negotiation of meaning, according to which, when communication problems occur between the students, they can still speak/write more slowly, simplify what has been said, change the vocabulary, choose more understandable topics, use simpler structures, paraphrase or even ask for more information and clarification from their peers. Considering their huge importance in ELT, these and other significant pedagogical rationales regarding the effectiveness of virtual realities in fostering genuine communication and collaboration among the students are the features that I want to examine in more details in my research.

\section{Research methodology}

In order to test my hypotheses, I examined the usefulness of VWs in real classroom settings. The experiment was conducted at SEE University (Tetovo, Macedonia) with undergraduate students of age 19-20, with intermediate level of English proficiency. What students had to do was meet with English native speakers and go on a virtual fieldtrip quest, searching for information about particular location while being engaged in social, immersive activities as a part of the quest's research. 
Book of Proceedings

International Conference on Computer Science and Communication Engineering

The objective behind the quest was to get students engaged in a task based activity so they can collaborate with their partners in order to accomplish their mission and thus acquire the target language spontaneously On the other hand, the qualitative data was gathered through questionnaires and surveys administered to the students, the ongoing observation, and comparison of the chat logs in order to see what communication conventions and strategies have been used while students accomplished their quest. The post task survey consisted of a series of questions, giving the students a chance to express their feelings and thoughts about the learning experience in SL, its advantages and disadvantages, and its impact on students' learning.

\section{Research findings}

The data collected showed that students using Virtual Worlds communicated more effectively then the students performing the role play. In this regard, the Virtual Worlds students greeted their partners, exchanged and shared experiences and negotiated meaning using communicative strategies more often than the students in the classroom setting. I also found that in the Virtual Worlds session the presence of the teacher was not necessary while the students were engaged in the conversations with the NSs, whereas the students in the classroom settings said themselves that the presence of the teacher was necessary who also triggered them to talk whenever they had communicational breakdowns. Virtual Worlds promoted real context for communication where students are stimulated to pay attention to conveying meaning rather than focusing on form. Moreover, the students had positive attitude towards their experience in Virtual Worlds.

In this study, Virtual Worlds indeed created a relaxing environment where students had free and casual conversation. Moreover, it promoted negotiation of meaning among the students and the NSs as students had the chance to improve the structure of their utterances when they were not understood by the interlocutors, using different communication strategies. Furthermore, this study showed that SL as an environment that triggered social negotiation among the users also helped them construct new knowledge by exploring the Virtual world environment. The findings from this study also suggests that in Virtual Worlds students established a sense of being together in an actual place with their interlocutor. In addition the study showed that students in Virtual Worlds showed great interest and willingness to collaborate which also creates a non-threatening environment for shy students.

\section{Conclusion and recommendation}

Teaching students communicative and collaboration skills has been one of the many challenges that researchers and practitioners in the field of ELT have faced. Considering communication as an important factor in language learning, this research examined how virtual simulations can contribute to solving this issue. As a matter of fact, virtual simulations have been shown to be successful in bringing students closer to the environment where language is learned naturally and spontaneously. As technology is developing and the students are becoming more and more technology literate, a medium that can help in creating communication and collaboration opportunities is more than welcomed. As such, VWs have shown great potential in enhancing these skills. Therefore, one of the biggest challenges for today's teachers is to find methods and strategies that will help them incorporate these new technological requirements in their teaching process.

I recommend that future study be conducted with larger sample group and in more sessions. Also, the study can be conducted with students of different language levels. Moreover, testing this problem with high school or even middle school students can bring different results. The study 
Improving non-native English students' communicative competence and collaboration skills through Virtual Simulations

can be done in two different schools so results can be compared between these two schools. A longitudinal study of improvements in communication and collaboration in SL can foster better research results. Furthermore, I also recommend a study with premium access to SL which can offer the students different options like owning their own place and building objects. This way they will be engaged in different SL functions which can also give them more opportunities to discuss different topics. In addition, the participants can be engaged in a group conversation rather than on chatting setting with one NS or they can even try to talk to non-NSs or their classmates. This way the researcher will be able to compare the experiences of the individuals within the same environment of SL. A future study investigating the use of text chat in SL for promoting communication and collaboration can provide a different perspective on text based communication between students and NSs.

\section{References}

1. Gee, J. P. (2001). Reading as situated language: A sociocognitive perspective. Journal of adolescent \& adult literacy, Vol.44, No.8.

2. Prensky, M. (2001). Digital Natives, Digital Immigrants: On the Horizon (MCB University Press), Vol.9, No.5.

3. Jung, H. J. (2002). Virtual reality for ESL Students. The internet TESL journal, Vol. 8, No.10. Retrieved17 June 2012 from: http://iteslj.org/Articles/Jung-VR.html.

4. Krashen, S. D. (1985). The input hypothesis. Oxford: Pergamon Press. 